\title{
Physico-Chemical Analysis of Waste Water from ACC Cement Industry from an Industrial Town - Ghugus (Maharashtra), India
}

\author{
L. S. Durge ${ }^{1}$, A.M. Chilke ${ }^{2}$,R. N. Chavhan ${ }^{3}$ \\ ${ }^{1}$ Department of Zoology, Dr. Ambedkar College of Arts, Commerce and Science, Chandrapur \\ ${ }^{2}$ Department of Zoology, Shri Shivaji College, Rajura \\ ${ }^{3}$ Department of Zoology,Mahatma Gandhi College, Armori,(M.S.), India
}

Available online at: www.isroset.org

Received: 11/Feb/2019, Accepted: 23/Feb/2019, Online: 28/Feb/2019

\begin{abstract}
There are different sources of industrial water pollution, but one of them is the discharge of harmful chemicals and compounds into the water bodies through gutters, due to which the water from the water bodies becomes unsuitable for the drinking and other domestic purposes. Though $72 \%$ of the earth surface is covered by the water, only 2.5 to 2.75 percent is fresh water of which 1.75 to $2 \%$ is frozen in glaciers, ice and snow, $0.5-0.75 \%$ as groundwater and moisture. Thus less than $0.01 \%$ is available to us as a surface water to us from lakes, ponds, rivers, reservoirs and streams only. So it is our prime duty to keep them clean for the survival of not only humans but for all the living beings on this earth planet. Therefor the systematic management of industrial run off is necessary for keeping the balance of an ecosystem. Therefor a pond situated at Nakoda, the water of which is used by the natives for many purposes including drinking is taken for the study of physic-chemical analysis.
\end{abstract}

Keywords: Physico-chemical, cement industry, effluent water, waste water, Nakoda pond,

\section{INTRODUCTION}

In previous days, wood was used as a main material in the building construction. But now a day's cement has taken its place. As cement industry is indispensable for the construction activity, it is playing a major role in improving the living standard of human society. Though cement industry is profitable, it is facing many challenging problems due to the environmental pollution and many other health issues as the effluents are entering in to the environment in its solid, liquid and gaseous state as byproducts of the cement. The ACC cement plant is situated near a village Nakoda $31 \mathrm{~km}$ from a district place Chandrapur in Maharashtra with latitude $19^{\circ} 55^{\prime} 50.88^{\prime \prime} \mathrm{N}$ and longitude $19^{\circ} 55^{\prime} 50.88^{\prime \prime} \mathrm{E}$.

Nakoda is a rural area and the inhabitants are engaged with cement industry, coal mining and other labour work. The raw materials used for the cement production are-limestone, gypsum iron and red alluvium and the major product of this industry is cement with different grades viz. CEM II/B-L $32, \% \mathrm{R}$ and CEM II/A-L42,5N.

Water is an essential factor in the manufacturing processes in every industry. An industrial effluent released in to the water bodies contains different chemicals and other harmful materials which can destroy an aquatic life. Also they may enter into the human body through various sources and will cause number of disorders in various body parts, and even may cause cancer. Manufacturing of cement is done in rotary kiln from the lime stone, gypsum, clay and other raw materials. The ratio of lime stone and clay is in the proportion of 3:1. This mixture is powdered and slurry is made by mixing water and poured in to the kiln. This slurry is burnt at about $1500^{\circ} \mathrm{C}$ with a flame from a coal or oil fire leaps up to the tower in a process known as calcination.Thus we get a mixture of silicates and aluminates of calcium which we call it cement.

Thus we get a useful product called cement but during the production of cement manufacturing, about $900 \mathrm{~kg}$ of $\mathrm{CO} 2$ is emitted for every $1000 \mathrm{~kg}$ of cement, which is harmful for living animals. The heavy metals like thallium, cadmium and mercury are also emitted which are most toxic. That why, the ACC Cement was taken for the study of physicochemical parameters.

\section{RELATED WORK}

Such type of work is carried out by E. E. Ekeng, S. E. Bejor and I. E. Ibiang in south region of Nigeria to assess the qualities of soil, water and air. D. Freeda Gnana Rani, K. Arunkumar and S.R. Sivakumar also performed the same type of work in Ariyalur Tamil Nadu. Though Chandrapur district is having 7-8 cement industries in and around the Chandrapur city, such type of work is not carried out in this particular area, and hence this work is taken for the study. 


\section{MATERIALS AND METHODS}

Mukutban an area from taluka Wani of Yeotmal disrrict is rich with lime stone deposits. And a village Nakoda is situated at the bank of river Wardha from where an ample supply of water is available to ACC cement industry. This is not an only cement industry in Chandraour district but there are again 7-8 cement industries in this district at Gadchandur in taluka Korpana as lime stone deposits are in abundance in this area.

The waste water discharged from the ACC cement industry in to the Nakoda pond was collected from two different sites and analyzed in to the laboratory. The waste water sample site 1 (WWS1) is mainly used for the irrigation purpose while waste water sample site 2 (WWS2) for the other domestic purposes by the natives of village Nakoda and other side by villagers. The temperature and $\mathrm{pH}$ were measured at the sampling sites itself, and for the measurement of other parameters the waste water samples were brought to the laboratory in the two liter capacity plastic cans labeled as WWS1 and WWS2. For the measurement of DO and BOD the said bottles were taken to sampling sites and after sampling closed tightly.The sampling was carried out during a period of December 2017.

Table 1:

Values of physic chemical parameters from two different sampling sites

\begin{tabular}{|c|l|l|l|}
\hline $\begin{array}{c}\text { Sr. } \\
\text { No. }\end{array}$ & Parameters & \multicolumn{1}{|c|}{ WWS1 } & \multicolumn{1}{|c|}{ WWS2 } \\
\hline 1 & Colour & colourless & Yellowish \\
\hline 2 & Odour & Fishy & Fishy \\
\hline 3 & Taste & Oily & Alkaline \\
\hline 4 & Turbidity & $11 \mathrm{NTU}$ & $16 \mathrm{NTU}$ \\
\hline 5 & Temperature & $28^{0} \mathrm{C}$ & $30^{\circ} \mathrm{C}$ \\
\hline 6 & Ph & 6.25 & 8.75 \\
\hline 7 & DO & $7.65 \mathrm{mg} / \mathrm{L}$ & $5.68 \mathrm{mg} / \mathrm{L}$ \\
\hline 8 & BOD & $23.7 \mathrm{mg} / \mathrm{L}$ & $21.3 \mathrm{mg} / \mathrm{L}$ \\
\hline 9 & COD & $10.3 \mathrm{mg} / \mathrm{L}$ & $08.7 \mathrm{mg} / \mathrm{L}$ \\
\hline 10 & $\begin{array}{l}\text { Total dissolved } \\
\text { solids }\end{array}$ & $198.95 \mathrm{mg} / \mathrm{L}$ & $768.45 \mathrm{mg} / \mathrm{L}$ \\
\hline 11 & Total hardness & $285 \mathrm{mg} / \mathrm{L}$ & $635 \mathrm{mg} / \mathrm{L}$ \\
\hline 12 & Chlorides & $122.35 \mathrm{mg} / \mathrm{L}$ & $540.23 \mathrm{mg} / \mathrm{L}$ \\
\hline 13 & Salinity $(\%)$ & 0.267 & 1.123 \\
\hline 14 & $\begin{array}{l}\text { Specific } \\
\text { conductivity }\end{array}$ & $257 \mathrm{mmhos} / \mathrm{cm}$ & $1154 \mathrm{mmhos} / \mathrm{cm}$ \\
\hline
\end{tabular}

\begin{tabular}{|c|l|l|l|}
\hline 15 & Total acidity & $10.39 \mathrm{mg} / \mathrm{L}$ & $7.24 \mathrm{mg} / \mathrm{L}$ \\
\hline 16 & Total alkalinity & $197.66 \mathrm{mg} / \mathrm{L}$ & $564.52 \mathrm{mg} / \mathrm{L}$ \\
\hline 17 & Carbonates & $36.76 \mathrm{mg} / \mathrm{L}$ & $96.56 \mathrm{mg} / \mathrm{L}$ \\
\hline 18 & Bicarbonates & $178.64 \mathrm{mg} / \mathrm{L}$ & $492.58 \mathrm{mg} / \mathrm{L}$ \\
\hline 19 & Phosphates & $0.0195 \mathrm{mg} / \mathrm{L}$ & $0.0162 \mathrm{mg} / \mathrm{L}$ \\
\hline
\end{tabular}

WWS1: Waste water sample 1

WWS2: Waste water sample 2

\section{RESULTS AND DISCUSSION}

The various physical and chemical parameters studied were colour, odour, taste, turbidity, temperature, $\mathrm{pH}, \mathrm{DO}, \mathrm{BOD}$, COD, total dissolved solids, total hardness, chlorides, salinity, specific conductivity, total acidity, total alkalinity, carbonates, bicarbonates and phosphates.

After comparing the values of various parameters with those of the of the tolerance limit values suggested by the

Maharashtra Pollution Control Board, it is found that the obtained values are within the standard values of Maharashtra Pollution Control Board.

With the increasing demand of water for irrigation purposes, it is profitable to use such waste water for the farmers of nearby areas and they should try to use it by giving due consideration for quality and quantity effluents. As the value of DO is much better, the water is found useful for irrigation purposes.

The obtained values of total chlorides, total hardness and total alkalinity of WWS 2are more than that of WWS 1.

As per the general guidelines of water use in agricultural irrigation (TDS $<500 \mathrm{mg} / \mathrm{L}$ and $\mathrm{SC}<0.75 \mathrm{mmhos} / \mathrm{cm}$ ) the water from WWS 1 is preferable for irrigation as compared to the water from WWS 2. Phosphorus is a good nutrient for the plant growth. But as the concentration values of bicarbonates and chlorides are more than $100 \mathrm{mg} / \mathrm{L}$, the waste waters from both the sites are found unsuitable particularly for sprinkle irrigation. The other parameter values viz. total acidity, turbidity and salinity are within the limit values. The oily taste of the water is due to the oils continuously applied to the machineries for lubrication, and the fishy odour is because of the continuous water circulation in cooling systems.

\section{CONCLUSSION}

The type of waste water released from the industries depends upon the size and type of an industry, the processes used by an industry and an amount of the water reused in the industry itself. The waste waters are reused if it is discriminated and treated separately by the biological and chemical methods. The enhancement in the quality and quantity of the waste water can be achieved by the regular monitoring of the waste water. 
By the analysis of the waste water from the two sites of Nakoda pond, a conclusion may be drawn that though the waste waters from both the sites is used directly for the irrigation purposes, it can be used for all types of irrigations like vegetable and fruit cultivation and also not to be used for the domestic purposes if the public adopts the better treatment processes. It is observed that the impurities in WWS 2 are due to the dissolved inorganic solids, and hence cannot be used for the drinking as well as other domestic purposes. It can be used for the irrigation and the domestic use if the purification methods like electro dialysis, reverse osmosis and ion exchange are dopted to make the waste water purification and make it suitable for all purposes (Peavy et at,1987).

\section{ACKNOWLEDGEMENT}

I acknowledge my vote of thanks to my guide Mr. A. M. Chilke, my collogue Mr. R. N. Chauhan for their valuable guidance. I am very much thankful to Mr. N. S. Kokode, Principal and Mr. Jayesh Hajare Head Department of Zoology of Nevajabai Hitkarini College, Bramhapuri, Maharashtra for extending permission and providing facilities to carry out this work in the research center of the college.

\section{REFERENCES}

[1]. Balasubramanian, M.R., Krishnamoorthy, S. and Murugesan. K. 1999. Engineering chemistry-A textbook. Allied Publishers Ltd. New Delhi p- 410.

[2]. Peavy, S., Howard, Donald, R., Rowe and George Tchobanoglous 1987. Environmental Engineering. McGraw- Hill Intenrational Editions, New Delhi. p -211.

[3]. Kudesia, V.P. 1996. Industrial Pollution. Pragati Prakashan, Meerut, U.P. p -42.

[4]. Kudesia, V.P. 1996. Indusrial Pollution. Pragati Prakashan, Meerut, U.P. p- 46.

[5]. Matkar, L.S. and Gangotri, M.S. 2003. Acute toxicity tests of sugar industrial effluents on the freshwater crab, Barytelphusa Guerini. Pollution Research. 22 (2) : 269-276.

[6]. Mishra, P.C. and Patel, R.K. 2004. Water pollution from major industries in Rourkela. The industrial city of Orissa, India. Proceedings of the 3rd national seminar on Inland Water Resources and Environment, organised by University of Kerala, p. 108-112.

[7]. Patel, K.P., Pandya, R.R., Maliwal, G.L., Patel, K.C. and Ramani V.P. 2003. Suitability of industrial effluents for irrigation around Bharuch and Ankleshwar industrial zone in Gujarat. Pollutin Research. 22 (2) : P 241-245.

[8]. Trivedy, R. K. and Goel, P.K. 1986. Chemical and Biological Methods of Water Pollution studies. Environmental Publications, Karad.

[9]. Vinod Kumar, Raina, A.K., Srivastava, R.K. and Singh, J.P. 2004. Waste Water: Problems and Prospects. Proceddings of the $3 r d$ national seminar on Inland Water Resources and Environment, Organised by Unviersity of Kerala. p 121-127

[10]. Patel, K.P., Pandya, R.R., Maliwal, G.L., Patel, K.C. and Ramani V.P. 2003. Suitability of industrial effluents for irrigation around
Bharuch and Ankleshwar industrial zone in Gujarat. Pollutin Research. 22 (2) : P 241-245.

[11]. Trivedy, R. K. and Goel, P.K. 1986. Chemical and Biological Methods of Water Pollution studies. Environmental Publications, Karad.

[12]. Matkar, L.S. and Gangotri, M.S. 2003. Acute toxicity tests of sugar industrial effluents on the freshwater crab, Barytelphusa Guerini. Pollution Research. 22 (2) : 269-276.

\section{AUTHORS PROFILE}

Mr. L.S. Durge completed his B.Sc.from St. Francis De'Sales College, Seminary Hills, Nagpur in 1984, and M.Sc. in 1986 with the specialization Fresh Water Zoology from institute of science, Nagpur, both the degrees from Nagpur University, Nagpur (M.S.) India. He worked as a Lecturer in Zoology at R.D. Science College, Aheri, Nabira Mahavidyalaya, Katol and Javahar Lal Nehru Science College, Saoner. At present he is working as an Associate Prof. with an experience of 25 years to U.G. and 15 years to P.G. classes at Dr. Ambedkar College of arts, Commerce and science, Chandrapur (M.S.), India. He is also engaged in social activities like participation in blood donation camps, awaring the people about family planning, etc.Currently he is doing Ph.D. from Gondwana University,Gadchiroli (M.S.), India. His area of research is Physico-Chemical Characteristics of a Fresh Water Pond of Ghugus, District Chandrapur, Maharashtra (India). Till today he published two International papers.

Mr. R. N. Chavhan completyed his B.Sc. in 1993 from Amaravati University and M.Sc. from the same University in 1996.he is awarded with Ph. D. Degree by R.T.M. Nagpur University in 2012. His topic of research was, "Limnological studies in respect to physic-chemical and biological characteristics of Ramsagar Lake, Armori,dist- Gadchiroli (M.S.) India".He worked on a U.G.C. sponsored minor research project entitled "Hydrological studies of some lentic ecosystems from Gadchiroli district of Maharastra state, India with respect to vertebrate fauna and Macro invertebrate species diversity" Sanctioned letter reference no.- F.No.47-1742/10 (WRO) Date:-25/5/2011. Total Sanctioned amount Rs.80000/-

At present he is working as an Assistant Prof. at Mahatma Gandhi Arts, Science and late N.P.Commerce College, Armori, DistrictGadchiroli 44120 (M.S.) Indiasince2000. He is registered as Ph. D. Superwiser at Gondwana University, Gadchiroliin 2013. He published 07 National and 10 International papers in different journals till now. He participated 35 Conferences, seminars and Work-shops with 15 abstracts, 3 posters and 17 oral presentations. 